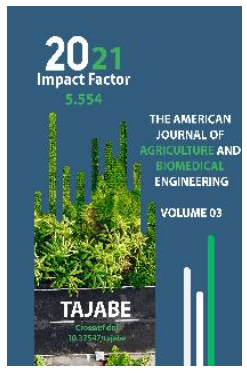

\title{
Useful Properties Of Cherries And Cherry Juice
}

\section{Xatamova X.K.}

Assistant, Andijan Institute Of Agriculture And Agrotechnologies, Uzbekistan

Yunusov O.B.

Assistant, Andijan Institute Of Agriculture And Agrotechnologies, Uzbekistan

Journal Website:

http://theamericanjour

nals.com/index.php/taj

abe

Copyright: Original

content from this work

may be used under the

terms of the creative

commons attributes

4.0 licence.

\section{ABSTRACT}

To study the process of obtaining natural juices from cherry fruit to satisfy people's thirst in summer and to recommend cherry juice to the owner.

\section{KEYWORDS}

Cherry varieties, cherry fruits, natural juice, apples, apricots, berries, canned, temperature, yield, sterilization.

\section{INTRODUCTION}

Summer has also begun. Hot days start in summer. Everyone starts drinking drinks that are comfortable for them to quench their thirst.

Natural juices are produced in a variety of assortments from fruits and berries. Juices are made from apples, apricots, peaches, strawberries and raspberries.

We recommend cherry juice for you based on our experience.
It is no secret that cherries are a very sweet and useful fruit. It is often eaten freshly cut, because in jams and other pastries made from it, cherries lose their flavor and useful properties.

Doctors recommend eating fruits and vegetables in moderation during the ripening season, with the exception of cherries, which contain large amounts of vitamins that protect the body from various infections and stimulate the growth of new immune cells. 
To make juice from cherries, we must first choose the best varieties of cherries, which contain a lot of juice.

Spring - early ripening universal variety. This variety, which starts the cherry season in Uzbekistan, is a mixture of Francis and Savri surkhani varieties. Moderately resistant to frost, adapted to the dry climate of the republic. The trees are strong, roundbranched, spreading, fruiting from the fourth year, the average yield is up to $50 \mathrm{~kg}$ at the age of ten.
The fruits ripen on May 5-10, large ( $8 \mathrm{~g}$ ), round, dark red in color, black when fully ripe. The flesh is dark red, dense, but soft, pleasant, the taste is very good. The beans are small and easily separated from the flesh. Resistant to transport and storage, the fruit does not shed on the tree until it withers. Eaten and canned in freshness, the compote is rated 5 points. This variety is grown in all regions of the republic.

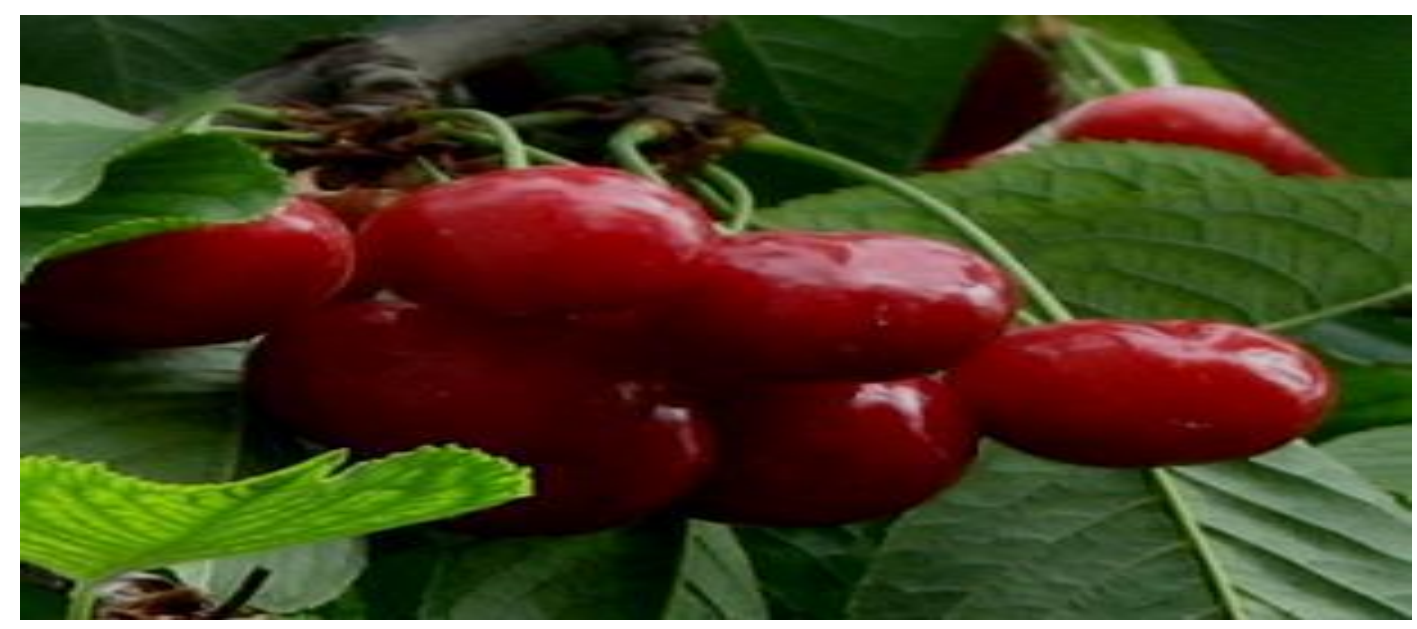

\section{(Spring variety of cherry)}

Kora geles is a local variety of national selection, early maturing, widespread in Samarkand region. The trees grow vigorously, live long, are more resistant to cold, adapted to the conditions of Uzbekistan. It begins to bear fruit in the third year and bears fruit every year. The fruits ripen on May 5-15.
Fruits are blunt, heart-shaped, bumpy, almost black, average weight $4 \mathrm{~g}$ Flesh is dark red, soft, juicy, juicy, the taste is very good. Durable and well kept. The seeds are small and well separated from the flesh. The fruit is eaten fresh, compote, jam is prepared, these products are rated 4.5 points. Black cherry variety is regionalized for all regions of Uzbekistan. 


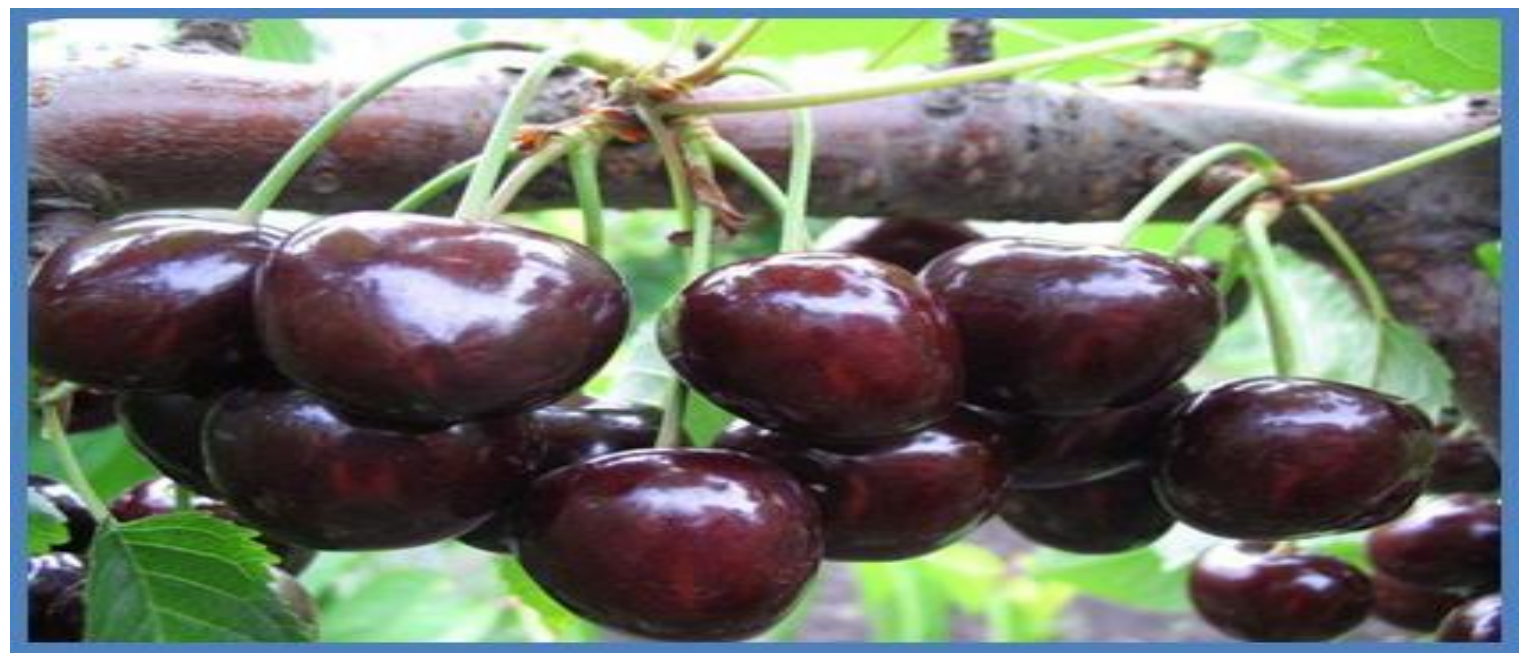

(Black cherry variety of cherry)

Yellow cherry (Drogana jeltaya) - universal use, suitable for flight, ovoid, more resistant to drought, yields annually from the age of four. By the age of 10, the yield reaches 100 $\mathrm{kg}$. This variety is partially self-pollinating, and is mainly well pollinated from Francis, Pink
Napoleon varieties. It ripens later-June 20-25. Fruits are round, yellow, large, average weight $-5 \mathrm{~g}$. The flesh is pale yellow, dense, juicy.

From the fruit is cooked compote and jam. This variety is regionalized throughout the country.

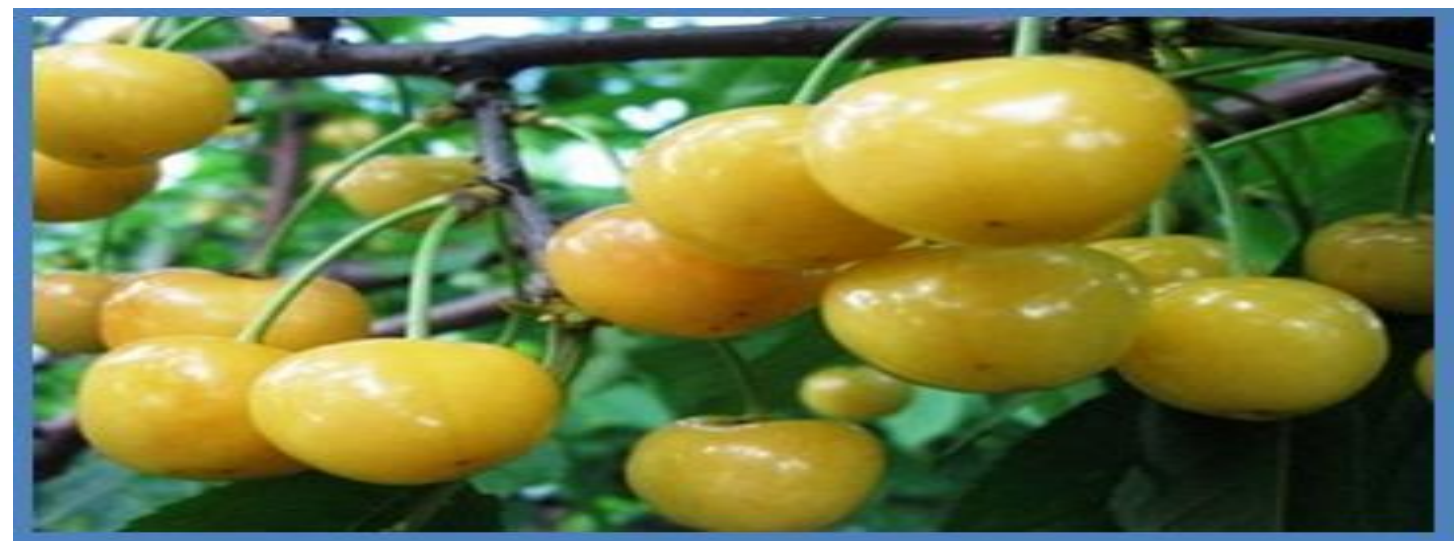

\section{(Yellow cherry (Drogana jeltaya) variety of cherry)}

Revershon - kschpishar, universal, usable variety. The trees are vigorous, broadly ovatebranched, more resistant to drought, moderately resistant to frost, well adapted to the local climate. Harvested from the age of five, at the age of 10 the yield reaches $60-65$ $\mathrm{kg}$ from each bush. Fruits ripen on May 25-30, large, average weight $7.5 \mathrm{~g}$, broad-hearted, dark red in color, very beautiful. The flesh is dark red, dense, crunchy, sweet, the taste is very good. The fruit is eaten fresh and 
The American Journal of Agriculture and Boimedical Engineering

I MPACT FACTOR (ISSN - 2689-1018)

Published: June 22, 2021| Pages: 6-12

Doi: https://doi.org/10.37547/tajabe/Volume03Issueo6-02

OCLC - 1121105746

compoteed. Revershon variety is regionalized for all regions of Uzbekistan.

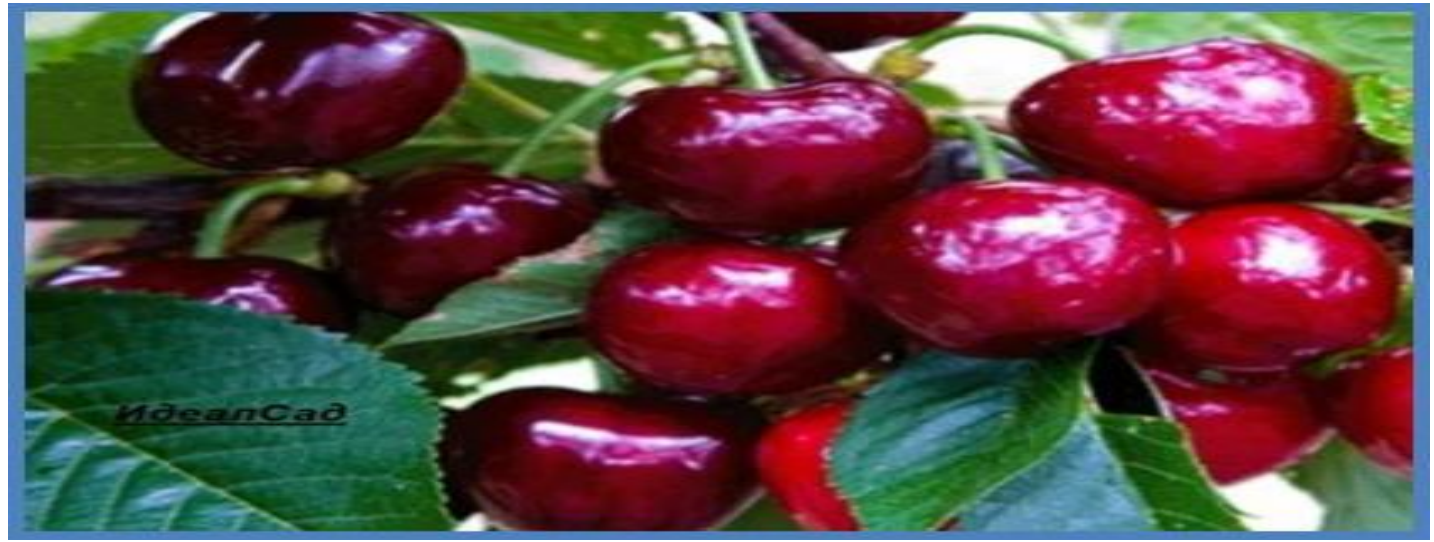

(Revershon variety of cherry)

We chose "Bahor" and "Kara geles" varieties of cherries for the experiment.
$70 \%$ natural juice was produced from "Bahor" variety. $60 \%$ of "Kara Geles" juice was produced.

The amount of juice output

\begin{tabular}{|c|c|c|c|}
\hline № & Methods & Juice output & Juice output (\%) \\
\hline 1. & 1. Method. Spring type & 70 & 30 \\
\hline 2. & 2. Method. Kara geles & 60 & 30 \\
\hline
\end{tabular}

All nutrients (sugars, acids, minerals, vitamins) are well preserved in canned fruit juices. Juices contain 5-15\% sugar and 0.3-3,096 organic acids.

In world medicine, cherries are not called "sweet medicine" in vain. It is rich in vitamins $B, A, C$ and RR. Cherries are a very powerful antioxidant and a weapon that boosts immunity. Cleanses the body of various radical bacteria. Maintains normal blood circulation.
Cherry juice is produced mainly in the form of meatless, soaked and sweetened, sometimes natural, as well as meaty and with the addition of sugar syrup.

Depending on the type of juice and brand navigation, the amount of dry matter is normalized in the range of $11-20 \%$, acidity - 0.6$2.4 \%$. The amount of meat can be up to $40 \%$.

The cherries obtained for processing are washed, inspected and ground in a two-roller grinder. The gap between the rollers should 
be $6-8 \mathrm{~mm}$, so that the amount of crushed fruit seeds does not exceed $20 \%$.

The juice is squeezed in hydraulic packing presses. Cherry juice keeps itself well. It is preserved in the cold for 24 hours, heated, mixed with sugar syrup, filtered and stored in a small container. Sometimes the semifinished product is prepared in 10-liter bottles, which are processed in season.

Modern equipment for the production of juices is characterized by high labor productivity and low manual labor costs. Therefore, during the harvest period, you can quickly process a significant portion of the crop and get the finished canned goods or semi-finished products and deliver them to the finished products during the less stressful period. As a result, the economic efficiency of the economy will increase significantly. In this regard, the processing of fruits and berries for juice is common.

The benefits of cherry juice are often underestimated. However, it is the most useful and nutritious of all juices. In addition, the levels of vitamins and antioxidants are much higher than in other fruits and fruit juices. Here are the best recipes for cherry juice.

Cherry juice is one of the most useful drinks, and it is also very tasty. Unfortunately, cherries are a seasonal plant and you can only enjoy their taste in the summer. If you want to enjoy your favorite drink in the cold season, you can make cherry juice for the winter.

Concluding from our experience, it can be said that drinking natural juices made from cherries in the summer months is not without its health benefits.

\section{REFERENCES}

1. Buriev X.Ch., Jo'raev R., Alimov O. Fruit and vegetable storage and preprocessing. - T .: Mehnat, 2002.

2. Khatamova, H. K., \& Kimsanova, K. A. (2020). The Peach Propagation Methods. The American Journal of Agriculture and Biomedical Engineering, 2(11), 42-46.

3. Вахабов, А., Салиев, С., Хатамова, Х., Кимсанова, Х., Якубова, З., \& Туланбоева, Г. (2017). ВЫРАЩИВАНИЕ МЕСТНЫХ СОРТОВ ТЫКВЫ В УСЛОВИЯХ ФЕРГАНСКОЙ ДОЛИНЫ И УСОВЕРШЕНСТВОВАНИЕ РАЗВИТИЯ СЕМЕНОВОДСТВА. In СОВРЕМЕННЫЕ ТЕНДЕНЦИИ РАЗВИТИЯ НАУКИ И ТЕХНОЛОГИЙ (рр. 84-86).

4. A.Vaxobov, S.A.Saliev, X.K.Khatamova "Technology of growing perennial hot pepper in pots at home" XXIII International Scientific and Practical Conference. Belgorod, February 28, 2017

5. Туйчиев, Ж. Ш., Убайдуллаев, С. Ш., Турдиева, Ф. Т., \& Солиева, М. Б. (2015). ИЗМЕНЕНИЕ ДОЛИ ДЕФЕКТНЫХ КОКОНОВ В ЗАВИСИМОСТИ ОТ СРОКОВ ПОСТУПЛЕНИЯ НА ЗАВОД. Современные тенденции развития науки и технологий, (4-2), 7881.

6. Sharipovich, A. A., Sheralievich, Y. N., Botirovna, S. M., \& Mukhammadovna, E. J. (2020). Study of methods for identification and storage of morphological features of grapes grown in the conditions of Fergana Region. The 
American Journal of Agriculture and Biomedical Engineering, 2(07), 20-24.

7. Sokhibova, N. S., Nazirova, M. I. K., \& Botirovna, S. M. (2020). INFLUENCE OF REARING SILK WORMS WITH HIGH PRODUCTIVE MULBERRY LEAVES ON THE BIOLOGICAL INDICATORS OF SILK GLAND AND RAW SILK EFFECTIVENESS. Life Sciences and Agriculture, (2).

8. Asronov, E. K., \& Soliyeva, M. B. (2020). The importance of feeding silkworms under polyethylene. ACADEMICIA: An International Multidisciplinary Research Journal, 10(10), 1169-1174.

9. Yuldasheva, K. T., Soliyeva, M. B., Kimsanova, X. A., Arabboev, A. A., \& Kayumova, S. A. (2021). Evaluation of winter frost resistance of cultivated varieties of olives. ACADEMICIA: AN INTERNATIONAL MULTIDISCIPLINARY RESEARCH JOURNAL, 11(2), 627-632.

10. Xatamova, X. K., Yuldasheva, K. T., Soliyeva, M. B., Kimsanova, X. A., \& Juraboyeva, S. M. (2021). Methods of preserving subtropical fruits. Asian Journal of Multidimensional Research (AJMR), 10(1), 109-115.

11. Yuldasheva, K. T., Soliyeva, M. B., Xatamova, X. K., \& Kimsanova, X. A. (2020). Effect of arbuscular mycorrhiza on micro propagated olive. ACADEMICIA: AN INTERNATIONAL MULTIDISCIPLINARY RESEARCH JOURNAL, 10(12), 1491-1498.

12. ВАХОБОВ, А., СОЛИЕВА, М., \& ХАТАMOBA, $\quad$ X. COPTA КРАСНОКОЧАННОЙ КАПУСТЫ ДЛЯ ПОВТОРНОЙ КУЛЬТУРЫ. ИРРИГАЦИЯМЕЛИОРАЦИЯ, 57.

13. Туйчиев, Ж. Ш., Мирзаев, Р. О., Солиева, М., \& Гафурова, Ю. К. (2016). ЗАВИСИМОСТЬ КАЧЕСТВА КОКОНОВ
ПЕРВИЧНОГО ПОКОЛЕНИЯ ОТ КОЛИЧЕСТВА ФОРМ ИЗМЕНЕННЫХ ИЗ ПАРТИИ ПЛЕМЕННЫХ. СовреМеннЫе тенденции развития науки $и$ технологий, 124.

14. Асронов, Э. К., \& Солиева, М. Б. (2020). ВЛИЯНИЕ ИЗМЕНЕНИЯ ТЕМПЕРАТУРЫ НА ПРОДУКТИВНОСТЬ И КАЧЕСТВО КОКОНОВ ВО ВРЕМЯ КОРМЛЕНИЯ ТУТОВОГО ШЕЛКОПРЯДА. ЭКономика и социум, (12-1), 388-391.

15. Асронов, Э. К., Салиева, М. Б., Салиев, С. А., \& Давлатов, Х. Р. (2018). ХРАНЕНИЕ ПЛОДООВОЩНОЙ ПРОДУКЦИИ. In Северный морской путь, водные и сухопутные транспортные коридоры как основа развития Сибири и Арктики в XXI веке (рp. 264-266).

16. Soliyeva, M. B., Yuldasheva, K. T., Xatamova, X. K., Kimsanova, X. A., \& Isroilova, S. S. (2021). The effect of shelf life of live cocoons on their temperature and quality. Asian Journal of Multidimensional Research (AJMR), 10(3), 254-260.

17. Soliyeva, M. B., Sh, T. J., \& Asronov, E. K. (2021). To Learn Of Biological And Productive Indicators Of Imported Mulberry Silkworm Breeds. The American Journal of Applied sciences, 3(04), 131-137.

18. Асронов, Э. К., \& Зайнобиддинов, М. (2014). Размножение тутовника на открытой местности древесными черенкамИ. In БИОРАЗНООБРАЗИЕ И РАЦИОНАЛЬНОЕ ИСПОЛЬЗОВАНИЕ ПРИРОДНЫХ РЕСУРСОВ (рp. 22-24).

19. Yuldasheva, K. T., Soliyeva, M. B., Daminov, X.E., Botirov, Sh.T., Mamadjanova,G.S. (2021). The process of growth of vegetative organs of olive seedlings in protected areas during the 
development phase.Asian Journal of Multidimensional Research (AJMR), 10(4), 287-293.

20. Xatamova, X. K., Soliyeva, M. B., Kimsanova, X. A., Yunusov, O. B., \& Yuldashev, R. T. (2021). Methods Of Drying Subtropical Fruits And Their Importance For Human Health. The American Journal of Applied sciences, 3(05), 148-154.

21. Хатамова, Х., Кимсанова, Х., \& ХУрматов, Й. (2018). ЦУКАТЫ ПЕРСИКА. In Фундаментальные и прикладные исследования в области естественных и технических наук (рр. 97-98).

22. Фахрутдинов, Н. З., Хамдамов, К. Қ., Хатамова, Х. К., \& Сафарова, Г. Қ. (2016). КАК АДАПТИРОВАТЬ ЦИТРУСОВЫЕ РАСТЕНИЯ В ДОМЕ?. СовРеМЕнные тенденции развития науки $и$ технологий, 126. 